\title{
DEBATE Entrevista da editoria da Revista Brasileira de Epidemiologia com a Dra. Maria Eneida de Almeida e com o Prof. Dr. Luis Hildebrando Pereira da Silva
}

Revista Brasileira de Epidemiologia - A proposta é a de fazer uma breve síntese do eixo principal da tese recentemente defendida pela Dra Eneida e em seguida passarmos aos comentários do Dr Hildebrando. Em particular, tentando resgatar um episódio que poucos conhecem: a experiência que o Prof. Samuel Pessoa - o grande mestre do Dr Luiz Hildebrando e de todos nós - teve numa comissão internacional que avaliou a guerra bacteriológica nos anos 50 na Coréia. Eneida, fale-nos um pouco sobre a sua tese.

Maria Eneida de Almeida - A idéia deste estudo foi tentar desvendar a relação que existe entre poder-bio/tecno/logia-guerra através da teoria da ciência política e de uma análise historiográfica. Porque, no século XIX, desde as décadas de 1860/70, quando do nascimento da microbiologia, esta começou a despertar o interesse militar. Dentro deste contexto acompanhamos as trajetórias do Desenvolvimento Biotecnológico e da Guerra Biológica partindo das duas grandes guerras do século $\mathrm{XX}$, quando foram implantados e sendo implementados os programas biológicos, em todas as Grandes Potências.

Para o campo do Desenvolvimento Biotecnológico, a descoberta do DNA em 1944 e de sua estrutura em 1953 foram grandes avanços científicos que potencializaram o armamento biológico. Por outro lado, no campo militar, a guerra da Coréia na década de 1950 e depois, do Vietnã, foram motivos legitimados que fomentaram a sofisticação de novos instrumentos, e agentes infecciosos cada vez mais letais. Porém, foi somente a partir da década de 1970, como um dos efeitos da revolução biotecnológica, que se deu um novo impulso para este tipo de guerra, com o desenvolvimento de agentes infecciosos geneticamente modificados para uso bélico.

O acompanhamento dessas trajetórias mostrou que os interesses político-militares foram sendo cada vez mais vinculados ao desenvolvimento da biologia, sobretudo após a II Guerra Mundial, quando a ponta tecnológica passou a ser a construção de armas de destruição em massa. Tendo em vista a propulsão tecnológica gerada a partir de então, a tese deste nosso estudo foi que, a partir da década de 1980 a Biotecnologia passou a ter um papel de destaque no planejamento estratégico das Grandes Potências como estratégia fundamental para a defesa nacional, e passou a ser um paradigma para a proteção das populações nacionais.

$\boldsymbol{R B E}$ - Em sua tese você analisa a disputa de poder que ocorreu nos Estados Unidos sobre o comando do Projeto Genoma Humano - a briga do NIH com outros setores, os setores de segurança, os setores estratégicos, ligados às forças armadas. Isso é um componente de análise muito interessante. Professor Hildebrando, fale um pouco sobre a Guerra da Coréia e o desenvolvimento de armas bacteriológicas àquela época.

Luís Hildebrando Pereira da Silva - Eu não sou historiador, mas posso dar certas informações que tenho sobre a experiência realizada pelos americanos na Coréia na tentativa de uso de armas biológicas em uma ação militar. Não houve, de acordo com o que pude depreender de minhas 
conversas com o Professor Samuel Pessoa, uma guerra bacteriológica propriamente dita, mas sim diversos e variados ensaios de armas biológicas em terreno militar durante o confronto. Fiquei sabendo disso porque convivi com o Professor Samuel em 1954, na Paraíba, quando ele, em sua vida de nômade científico, assumiu a responsabilidade sobre o laboratório de parasitologia da nova Faculdade de Medicina da Paraíba e eu o acompanhei como assistente. O Prof. Samuel Pessoa estava em Maceió em 1952 e foi procurado por Fued Saad, Professor Assistente de Urologia da Faculdade de Medicina da USP, que era membro do Conselho Mundial da Paz, com sede em Paris, dirigido pelo premio Nobel de Física Joliot-Curie.

Este conselho constituiu uma Comissão Internacional para investigar as acusações sobre Guerra Bacteriológica na Coréia, pois havia denúncias do governo chinês de que o governo da Coréia do Sul havia autorizado os Estados Unidos a desenvolver ações militares de guerra bacteriológica. Essa Comissão Internacional era composta de uma cientista sueca - antiga diretora do Laboratório de Saúde Pública de Estocolmo - o Professor Malterre, professor de microbiologia da Faculdade de Agronomia de Rennes, da França, o professor Zhukov Verechinikov, da Academia de Ciências da URSS, o nosso Samuel Pessoa, professor de Parasitologia da USP, o professor de anatomia e histologia de Bologna, Oliverio Olivo e, seu assistente, um jovem pesquisador em Microbiologia, Franco Graziozi, que mais tarde foi Diretor do Instituto de Genética e Biofísica da Universidade de Nápoles e professor emérito de Microbiologia da Universidade de Roma.

Os nomes mais importantes deste grupo eram Joseph Needham, bioquímico da Universidade de Cambridge, e grande conhecedor da cultura chinesa, fluente na língua chinesa, e o Prof. Samuel Pessoa, que era o único parasitologista da Comissão, o que teve repercussões muito interessantes no decorrer dos trabalhos.
Eles trabalharam na área de fronteira da China com a Coréia. Isso resultou num grande documento, um livro, o relatório da comissão internacional de investigação sobre a Guerra biológica na Coréia, que foi editado pela Editora de línguas estrangeiras de Moscou em várias línguas.

Havia várias cópias desse documento no Brasil, inclusive em minha biblioteca, mas infelizmente durante o golpe militar no Brasil de 1964 houve investigações e invasões ao meu domicilio e minha biblioteca foi devastada, devidamente expurgada, e perdi o documento.

Depois estive na França e procurei este relatório na Biblioteca Nacional, mas não encontrei mais.

Houve sim, segundo Samuel Pessoa, ensaios de armas bacteriológicas e isso não era um segredo militar pois citações de vários artigos publicados em revistas científicas sobre armas bacteriológicas constavam desse relatório. Vários países do lado da União Soviética também faziam este tipo de experiência. Nos Estados Unidos, inclusive, existia uma instituição oficial para estudos que era o Instituto de Fort Dietrich, localizado no Arizona, ou no Texas, com a participação de vários cientistas conhecidos, microbiologistas e imunologistas entre eles. No próprio relatório havia referencias a trabalhos americanos mostrando o isolamento de germes virulentos e a possibilidade de utilização disso como arma biológica. Isso continuou durante vários anos e somente ao fim da Guerra fria o instituto foi fechado e essas pesquisas provavelmente ficaram restritas a situações um pouco mais, digamos, secretas e confidenciais.

Do lado soviético nunca houve uma divulgação ou mesmo transparência com relação a isto, mas eles devem provavelmente ter se utilizado de experiências do mesmo tipo, mas não utilizando em terreno. Os japoneses já tinham utilizado contra a China esses mesmos instrumentos de armas biológicas.

Os fatos interessantes que foram utilizados pelos americanos, segundo o que foi 
demonstrado pela Comissão foi o uso de germens virulentos, isso muito antes de analises do genoma (o que se sabia de virulência bacteriana era mais que suficiente para montagem de instrumentos de ataques biológicos), pois o fato de você poder modificar geneticamente e de forma mais controlada a virulência das bactérias pode facilitar o desenvolvimento de certas armas, mas isso já existia na década de 40 e 50 . O que havia de novo na Guerra da Coréia era mesmo uma ameaça de intervenções nucleares. O chefe de operações militares da época, o General Mac Arthur, segundo o que se comentava na imprensa, queria empregar armas nucleares contra coreanos e chineses, mas houve grande resistência porque os soviéticos já haviam desenvolvido experiências atômicas e este ataque poderia ser voltado também contra os Estados Unidos. O General Mac Arthur acabou sendo substituído no comando.

Essas experiências de guerra bacteriológica foram realizadas principalmente em 1951 e 1952. O Prof. Samuel Pessoa esteve lá em 1952 e relatou-me que, por exemplo, os membros da Comissão observaram que, pelas autopsias que os chineses mostraram, existiam dezenas de casos de vitimas de peste pulmonar numa localidade em que não havia possibilidade de epidemia ou endemia de peste pulmonar.

Além disso, isolaram grande quantidade de pulgas da espécie Pulex irritans coletadas numa área rural, que não é ambiente natural deste tipo de pulga. Essa pulga não é vetor natural de peste, somente exerce esse papel, normalmente desempenhado pela pulga do rato, quando há hiper epidemias. Eles encontraram milhares de pulgas que foram capturadas na localidade, em área rural, infectadas pelo bacilo da peste - por ser um absurdo do ponto de vista epidemiológico, foi descrito como sendo um dos indicadores de uma possível estratégia de guerra bacteriológica. Eles encontraram também em certas áreas grandes coleções de ostras infectadas por salmonelas e também referências à formação de aerossóis infectados.
Eram vários fatos que poderiam ser explicados também como uma grande encenação feita pelos chineses e pelos coreanos. Não existia prova de que tinham sido os americanos, mas tão somente evidências de ações que correspondiam a técnicas descritas pelos artigos publicados pelos pesquisadores do próprio Fort Dietrich que eram exatamente essas observadas. Era um grande volume de páginas cheias deste tipo de evidência. Samuel Pessoa participou ativamente disto porque quando começaram a capturar insetos, pulgas, ostras, o Needham queria mandar isso para o Museu Britânico para analise e o Samuel bateu o pé e disse que, sendo parasitologista, ele mesmo poderia fazer a identificação dos insetos encontrados. Nesse sentido, a participação do Dr. Samuel foi de grande importância.

O fato mais recente em relação a Comissão Internacional deu-se em 1964/1965 quando o Joseph Needham escreveu uma carta para o Samuel Pessoa dizendo que um dos pilotos envolvidos nessas ações militares na época da Guerra da Coréia teve crises de consciência e revelou essas ações, sendo considerado demente e, posteriormente, preso. Needham então escreveu uma carta ao professor em que dizia: "pois é, Pessoa... este piloto foi preso e afastado... ninguém mais fala em guerra bacteriológica e vão acaba dizendo que foi tudo invenção nossa..."

Em 1995 Joseph Needham morreu e fizeram um grande necrológio, pois ele era um bioquímico muito famoso na Inglaterra. Ele foi lembrado como autor de uma Embriologia Química em três volumes escrita em 1930 e por sua monumental obra em 17 volumes sobre Historia das Ciências e da Civilização Chinesa publicada em 1954. O jornal Le Monde publicou um necrológio com todos os elogios dizendo que ele era um grande bioquímico, conhecedor da cultura chinesa, mas que ao final de sua vida tinha se envolvido com socialistas e que participou das denúncias de existência de "Guerra química" na Coréia. Eu escrevi uma carta ao Le Monde dizen- 
do que tinha sido discípulo do Prof. Samuel Pessoa, um outro membro da Comissão Internacional de Investigação da guerra bacteriológica e que ele me mostrara a carta do Needham dizendo que acabariam por esquecer toda a história, mas que foi pior que isso, pois falsificaram a história dizendo que ele havia participado da investigação sobre guerra química, o que nunca aconteceu. Essa minha carta nunca foi publicada.

$\boldsymbol{R B E}$ - O que você acha da idéia de que o desenvolvimento da biologia molecular moderna, o projeto genoma humano, tem associação íntima com os interesses estratégicos das grandes potências da chamada big science?

LHPS - Há, em certos setores da opinião pública um conteúdo de diabolização da biologia moderna, da biologia molecular e da biotecnologia. Evidentemente as grandes potências, as grandes indústrias e a grande finança não desenvolvem produtos que são necessários para resolver os problemas das doenças negligenciadas. Estamos aqui reunidos - os burocratas da ciência brasileira - para resolver este tipo de problema*. Quer dizer, negligencia-se algo que é de grande interesse para a Saúde Pública nacional e internacional a respeito das populações pobres das áreas menos desenvolvidas do país que são vitimas de malária, de esquistossomose, tuberculose, leishmaniose, hepatite, lepra,... Evidentemente, as questões relacionadas à fecundidade humana e deficiências sexuais têm maior investimento porque há garantia de maior rentabilidade.

As perspectivas de reforço do poder militar estratégico dos países industrializados mais ricos recebem todo o financiamento necessário, e da mesma maneira o setor farmacológico. Mas não podemos atribuir a um elemento de intenção maléfica dominante na área da Biologia molecular como sendo o mecanismo de ativa- ção ou desenvolvimento de setores da ciência atual que têm, por outro lado, possibilidades de repercussão em favor da saúde humana e do bem estar que são incomensuráveis em termos de possibilidade de controle de doenças de natureza genética. O desenvolvimento de um medicamento para resolver uma doença genética como a hemofilia, por exemplo, ou a anemia falciforme, daria grandes lucros e isso por si só já e motivo de investimento na área da biotecnologia, dos transgênicos e da terapia gênica evidentemente. Mas o setor militar é muito favorável a este desenvolvimento no sentido de que essa produção pode possibilitar a criação de armas biológicas mais potentes e talvez mais específicas, ou com alvos mais precisos. Isso pode ser um elemento, mas eu não aceito que seja o elemento dominante.

MEA - Eu considero importante sublinhar que quando se fala em Big Science a palavra 'intenção' não se encaixa. Tentarei explicar em poucas palavras. Nossa investigação através da história com base na teoria da ciência política nos permitiu identificar que, desde o século XVII no nascimento do Sistema Mundial Moderno que se deu na mesma hora do nascimento da Ciência Moderna, o poder e a ciência são estreitamente vinculados, sendo que a construção de armas de última geração elevam os Estados na hierarquia de poder mundial. Buscamos compreender, por meio dos movimentos do poder e da guerra, isto é, analisando com exclusividade o campo político-militar da ciência, 'como', 'por que' e 'de que forma' a ciência ganha impulso. Ou ainda, buscamos captar de onde vem a inexorabilidade da ciência. $\mathrm{E}$ fizemos isso através de um contraponto entre o caso da Física que abriu a era atômica, e o caso da Biotecnologia, que abriu a era biotecnológica ou era genômica, como está sendo referida.

Ao acompanhar o Desenvolvimento

*A entrevista foi realizada no Hotel Othon, em Copacabana, no dia 6 de abril de 2006, num intervalo da "Oficina de prioridades de Pesquisa e Inovação em Doenças Negligenciadas" 
Biotecnológico verificamos que, desde a descoberta do DNA e de sua estrutura, os cientistas-estrategistas sabiam que este conhecimento técnico aperfeiçoaria os armamentos para a Guerra Biológica. Verificamos também que a revolução biotecnológica fundamentou todo um novo programa biológico nos Estados Unidos e na União Soviética. As ameaças passaram a ser das chamadas armas exóticas, que são armas de destruição em massa com munição de agentes infecciosos geneticamente modificados. Este contexto nos levou a pesquisar os movimentos de poder de guerra dos Estados e sua ligação com a ciência estratégica, a qual responde ao campo político-militar das Grandes Potências. Esta ciência estratégica é a ponta tecnológica da ciência. E quem a impulsiona, em primeira instância, é o Estado que terá a liderança da ponta científica no mundo. E foi no desenvolvimento deste raciocínio que encontramos a Big Science.

Na era atômica, a ciência predominante era a Física e os Estados Unidos detiveram, e detém, por todo o tempo a liderança tecnológica no mundo. Na era biotecnológica é a biologia a ciência predominante e, desde o ano 2000, com o anúncio efusivo do rascunho do genoma humano, os Estados Unidos detém a liderança biotecnológica no mundo. Esta liderança, do nosso ponto de vista, significa o interesse militar do Estado que conduz ou guia a ciência estratégica, e isto recai sobre a Ciência como um todo. Isto é um efeito natural porque o interesse em determinada ciência proporciona os maiores financiamentos para pesquisas básicas e aplicadas; sendo que as que têm o interesse em declínio ou não são interessantes, recebem menor financiamento ou simplesmente não recebem. É desta perspectiva que o interesse político-militar mobiliza o mecanismo da Big Science, e leva a ciência estratégica para a ponta tecnológica.

A Big Science está na esfera da ameaça, cada vez maior. Quanto maior o avanço tecnológico, mais possibilidade do Estado estar à frente na corrida armamentista ou ultrapassar o que está à frente dele. Entendemos que é a ameaça que estimula a busca pela liderança da ponta científica na corrida armamentista. Desde o início da era atômica a grande ameaça são as armas de destruição em massa - a bomba atômica. Isso mudou todo um conjunto de estratégias de guerra, e a alta tecnologia sustentou o mecanismo da Big Science, e deu à Física o status de ciência central. Buscamos compreender de que forma a Biotecnologia levou a biologia a suplantar os financiamentos da própria Física, ganhando elevado status para o poder dos Estados. E isto aconteceu nas últimas décadas do século XX. De que forma isto teria se dado?

Neste sentido é que não sei bem se seria uma questão de diabolização, porque não há 'intenção' de quem quer que seja. Porque não existe uma escolha da ciência estratégica. Ninguém escolheu a Física uma vez, da mesma forma que não houve nenhuma escolha da Biologia mais recentemente. Não há um fator determinante, simplesmente os interesses militares se entrelaçam com o desenvolvimento da ponta tecnológica para a manutenção da liderança científica no mundo, pois isso dá o primeiro lugar na corrida armamentista, com produção de armamentos radicais de primeira linha. E verificamos que o Projeto Genoma Humano foi o primeiro projeto da Big Science no campo da biologia. Desta forma buscamos entender de que forma as coisas se entrelaçam, a despeito do valor humano da ciência da biologia que prioriza as pesquisas para a vida e não para a morte.

$\boldsymbol{R B E}$ - A Eneida explora na tese o duplo sentido da modernização, desse desenvolvimento: o uso dual da modernização.

LHPS - Existe uma diabolização inclusive dos transgênicos vegetais. Nesse caso, ninguém usa muito a diabolização no sentido militar, mas tão somente em relação aos interesses das grandes multinacionais no crescimento econômico financeiro. Diaboliza-se a intenção do ganho financeiro como é uma ameaça à vida e ao ambiente. 
Ora, não se inventou a eletricidade por causa da cadeira elétrica. Não se inventou a energia nuclear para realizar a bomba atômica. Mas atualmente há grandes reticências sobre as conseqüências dos desenvolvimentos e usos de materiais como o petróleo, por exemplo, mas por outro lado este uso representou para a humanidade um progresso fantástico e a melhoria das condições de vida, mas que tem seu lado negativo.

A vida da humanidade está cheia desses aspectos positivos, negativos e contraditórios do progresso humano, levando a conseqüências possíveis em todas as direções. A grande pergunta que se deve fazer é se o homem será capaz de resolver todas essas contradições que ele está criando da forma como ele vem conduzindo o processo civilizatório ou se não vai ficar parado numa destas questões e se isso não vai levar ao desaparecimento da espécie. Isso é a grande questão filosófica que se coloca ao processo civilizatório e que estamos enfrentando hoje em dia.

O aspecto militar é um dos aspectos. Mas talvez não seja o mais grave, de certo modo, porque o equilíbrio do terror que está sendo criado internacionalmente leva a esse equilíbrio instável de confrontação. Os americanos chegaram à conclusão de que a arma biológica não é uma arma de grandes perspectivas, porque na verdade é difícil manipular o sistema e controlar sua extensão. Eles fizeram ensaios e em nenhum dos casos aparentemente há conclusões definitivas se essas armas têm grande eficiência, a não ser em condições muito particulares e específicas. Caso seja preciso cercar e acabar com a população de uma ilha talvez isso seja uma arma invencível, mas nas situações de confronto atuais não se leva isso à realização, porque uma vez que você contamina uma área ela não pode ser mais usada, e você está sujeito ao mesmo agente. Não é o caso da guerra atômica, ou da guerra química. A guerra bacteriológica provavelmente foi um pouco encostada como perspectiva militar de alta potencialidade por causa dos efeitos negativos que encerram essa hipótese. Não precisa ficar com medo da biotecnologia... eu acho que não é esse o grande perigo da humanidade.

MEA - Considero importante enfatizar de que, do nosso ponto de vista, a Big Science é mobilizada mais pela ameaça do que pela possibilidade de uso de seus produtos. Por exemplo, conforme foi se dando o acirramento da Guerra Fria, mais e mais bombas atômicas, cada vez mais sofisticadas foram sendo construídas, servindo este fato, de estímulo à tecnologia mais sofisticada para os armamentos. E isso não significa que as bombas seriam usadas, como jamais foram depois de Hiroshima e Nagasaki. Por isso trabalhamos mais com o aspecto da ameaça do que da guerra propriamento dita, quando falamos de Big Science.

Pois bem, e temos o Relatório da National Academy of Science dos Estados Unidos que sinaliza o grande desafio dos dias atuais, como sendo o problema da próxima geração das armas biológicas. Desde 1970 nós estamos na terceira geração deste tipo de armamento, e a preocupação gira em torno da quarta. Este fato vem justificando o fechamento de uma grande parte dos investimentos na ciência básica da biologia, no mundo. $\mathrm{E}$ isto não é uma questão de medo, mas sim de fatos que vêm acontecendo. Estes fatos estão publicados e é deles que estamos falando porque este Relatório fornece a direção da pesquisa básica no campo da biologia, chegando até aos riscos de uso dual das pesquisas nanobiotecnológicas para o campo militar.

RBE - Obrigado! A Abrasco e a Revista Brasileira de Epidemiologia agradecem.

Nota adicionada em novembro de 2006 por LHPS. “Fui informado que o Professor Franco Graziozi , está vivo, com boa saúde e reside em Roma. Ele é o último sobrevivente da Comissão Internacional e depositou documentos com seus testemunhos as atividades da Comissão Internacional em 2003 no Imperial War Museum de Londres." 